\title{
DEVELOPMENT AND STABILITY INDICATING HPLC METHOD FOR DAPAGLIFLOZIN IN API AND PHARMACEUTICAL DOSAGE FORM
}

\author{
MITALI V. VERMA ${ }^{\mathrm{a}}$, CHIRAG J. PATEL ${ }^{\mathrm{b}}$, M. M. PATEL $^{\mathrm{c}}$
}

$a^{*}$ Department of Pharmaceutical Analysis, Gujarat Technological University, Ahmedabad, Gujarat, India, bDepartment of Pharmaceutical Analysis, Shree Swaminarayan Sanskar Pharmacy College, Gandhinagar, Gujarat, India, cShree Swaminarayan Sanskar Pharmacy College,

Gandhinagar, Gujarat, India

Email: mitaliv02@gmail.com

Received: 13 Apr 2017, Revised and Accepted: 22 Aug 2017

\section{ABSTRACT}

Objective: To develop precise, accurate and reproducible stability assay method by RP-HPLC for estimation of dapagliflozin in API and pharmaceutical dosage form.

Methods: The adequate separation was carried using agilent C18 (4.6 ml (millimeter)*150,5 $\mu$ m (micromiter), mixture of acetonitrile: di-potassium hydrogen phosphate with pH-6.5 adjusted with OPA (40:60 \% v/v) as a mobile phase with the flow rate of $1 \mathrm{ml} / \mathrm{min}$ (milliliter/minute) and the effluent was monitored at $222 \mathrm{~nm}$ (nanometer) using photo diode array detector. The retention time of dapagliflozin API and dapagliflozin tablet were $3.160 \mathrm{~min}$ (minute) and $3.067 \mathrm{~min}$ (minute) respectively.

Results: Linearity for dapagliflozin was found in the range of $50-150 \mu \mathrm{g} / \mathrm{ml}$ (microgram/milliliter) $\left(\mathrm{R}^{2}=0.99\right)$ respectively. The accuracy of the present method was evaluated at $50 \%, 100 \%$ and 150\%. The \% recoveries of dapagliflozin API and tablet were found to be in the range of $99.00-$ $99.99 \%$ and $98.50-99.99 \%$ respectively. Precision studies were carried out and the relative standard deviation values were less than two. The method was found to be robust.

Conclusion: The proposed method was found to be specific, accurate, precise and robust can be used for estimation of dapagliflozin in API and Pharmaceutical dosage form.

Keywords: HPLC, Dapagliflozin, API, Pharmaceutical dosage form, OPA

(C) 2017 The Authors. Published by Innovare Academic Sciences Pvt Ltd. This is an open access article under the CC BY license (http://creativecommons.org/licenses/by/4.0/) DOI: http://dx.doi.org/10.22159/ijap.2017v9i5.19185

\section{INTRODUCTION}

Dapagliflozin is chemically a $(2 \mathrm{~S}, 3 \mathrm{R} .4 \mathrm{R}, 5 \mathrm{~S}, 6 \mathrm{R})-2-[4-$ chloro-3-(4ethoxybenzyl)phenyl]-6-(hydroxymethyl)tetrahydro 2H-pyran3,4,5-triol) with molecular weight of $408.873 \mathrm{~g} / \mathrm{mol}$.

Dapagliflozin is a sodium glucose co transpoter inhibitor (antidiabetic drug), which prevents glucose reabsorption in the kidney. Thus leads to the elimination of glucose through urine [1-2].

Various analytical methods have been reported for dapagliflozin alone and in combination with metformin hydrochloride. Methods such as UV spectroscopy for estimation of dapagliflozin alone or in combination with metformin hydrochloride [3-7, 9], HPLC method for estimation of dapagliflozin and metformin hydrochloride [8] and alone dapagliflozin in API [10], LC MS/MS for dapagliflozin [11] has been reported.

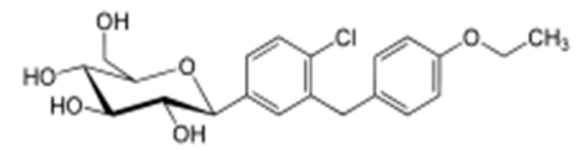

Fig. 1: Structure of dapagliflozin from pubmed

However, an extensive literature search didn't reveal any estimation method for dapagliflozin in API and Pharmaceutical dosage form. Therefore an attempt has been made to develop and validate simple, precise, accurate HPLC method for estimation of dapagliflozin in API and Pharmaceutical dosage form.

\section{MATERIALS AND METHODS}

Drugs, chemicals and solvents: Dapagliflozin in API was kindly given by advanced analytical research and training institute, gujarat. All the chemicals and solvents used were of analytical grade.

\section{Instruments}

The analysis was performed on agilent HPLC fitted with a gradient pump photo diode array detector and agilent C18 (4.6 mm150,5 $\mu \mathrm{m})$ column which is maintained at an ambient temperature. The optimized mobile phase composition was a mixture of acetonitrile: dipotassium hydrogen phosphate with $\mathrm{pH} 6.5$ adjusted with OPA $(40: 60 \% \mathrm{v} / \mathrm{v})$ with a flow rate of $1 \mathrm{ml} / \mathrm{min}$. The injection volume was $20 \mu$. The chromatographic run time was adjusted to $6 \mathrm{~min}$. The wavelength of the detector was set at $222 \mathrm{~nm}$ for analysis of the drug.

\section{Preparation of buffer}

Dissolve 0.435 gm (gram) of dipotassium hydrogen phosphate in $100 \mathrm{ml}$ (milliliter) of HPLC water. Filter the solution through $0.45 \mu$ nylon filter. Adjust the pH-6.5 with dilute orthophosphoric acid and degas before use.

\section{Preparation of mobile phase}

Prepare a mixture of buffer (dipotassium hydrogen phosphate) and acetonitrile in the ratio of 60:40. Adjust the $\mathrm{pH} 6.5$ with diluted ortho phosphoric acid (OPA). This solution was sonicated for $5 \mathrm{~min}$ (minute) for degassing and filtered through $0.45 \mu$ millipore filter.

\section{Diluent}

The drug was dissolved in acetonitrile.

Preparation of standard stock solution (API)

Accurately weighed $10 \mathrm{mg}$ (milligram) of dapagliflozin was taken in a $10 \mathrm{ml}$ standard volumetric flask and dissolved in few $\mathrm{ml}$ of acetonitrile. Then the volume was made up to the mark with acetonitrile. From the above solution, $5 \mathrm{ml}$ was diluted to $10 \mathrm{ml}$ with to get a concentration of $500 \mu \mathrm{g} / \mathrm{ml}$ of dapagliflozin.

\section{Preparation of standard stock solution (tablet)}

The average of 10 tablets was determined and grounded in a mortar. An accurately weighed amount of powder equivalent to $10 \mathrm{mg}$ of 
dapagliflozin was taken. It was transferred to $10 \mathrm{ml}$ of volumetric flask. Add $5 \mathrm{ml}$ of diluents and sonicated for $5 \mathrm{~min}$ to ensure complete solubilization of drug after sonication, volume was made up to the mark with diluents $(1000 \mu \mathrm{g} / \mathrm{ml}$ of dapagliflozin stock solution). Pipette out $5 \mathrm{ml}$ from above solution and dilute up to 10 $\mathrm{ml}$ with diluents (500 $\mu \mathrm{g} / \mathrm{ml}$ of dapagliflozin).

\section{Calibration curve}

Aliquots of different concentrations of standard solution were prepared and their chromatograms were recorded at the optimized chromatographic conditions. The mean peak areas at different concentration levels were calculated from the chromatograms. Then the linearity plot was constructed using the mean peak areas at their respective concentrations fig. 14 .

\section{Forced degradation study}

Forced degradation study of dapagliflozin in API and pharmaceutical dosage form was carried out under different stress conditions as mentioned in ICH guideline Q1A (R2). The standard solution containing $500 \mu \mathrm{g} / \mathrm{ml}$ of dapagliflozin API and $500 \mu \mathrm{g} / \mathrm{ml}$ of dapagliflozin tablet were subjected to acid, alkali hydrolysis, peroxide, thermal and photolytic degradation.

\section{Acid degradation}

Transfer $1 \mathrm{ml}$ of standard solution to $10 \mathrm{ml}$ of volumetric flask. Add $1 \mathrm{ml}$ of $0.1 \mathrm{~N} \mathrm{HCl}$ keep the volumetric flask in water bath at $60^{\circ} \mathrm{C}$ for $2 \mathrm{~h}$. After time period cool the contents to ambient temperature. Neutralized the solution with $1 \mathrm{ml}$ of $0.1 \mathrm{~N} \mathrm{NaOH}$ and volume was made up to $10 \mathrm{ml}$ with diluent. After inject the acid degradation sample into HPLC, peak area and peak shapes were observed fig. 2 .

\section{Procedure for tablet}

The average of 10 tablets was determined and grounded in mortar. An accurately weighed amount of powder equivalent to $10 \mathrm{mg}$ of dapagliflozin was taken. It was transferred to $10 \mathrm{ml}$ of volumetric flask. Add $5 \mathrm{ml}$ of diluents and sonicated for $5 \mathrm{~min}$ to ensure complete solubilization of drug. After sonication, volume was made up to the mark with diluent $(1000 \mu \mathrm{g} / \mathrm{ml}$ of dapagliflozin stock solution). Pipette out $5 \mathrm{ml}$ from above solution and dilute up to 10 $\mathrm{ml}$ with diluent ( $500 \mu \mathrm{g} / \mathrm{ml}$ of dapagliflozin). Pipette out $1 \mathrm{ml}$ from the sample solution and add $1 \mathrm{ml}$ of $0.1 \mathrm{~N} \mathrm{HCl}$ and keep at $60{ }^{\circ} \mathrm{C}$ in water bath for $2 \mathrm{~h}$. After time period cool the contents to ambient temperature. Neutralized the solution with $1 \mathrm{ml}$ of $0.1 \mathrm{~N} \mathrm{NaOH}$ and volume was made up to $10 \mathrm{ml}$ with diluents. After inject the acid degradation sample into HPLC,peak area and peak shape were observed fig. 3.

\section{Base degradation}

\section{Procedure for API}

Transfer $1 \mathrm{ml}$ of standard solution to $10 \mathrm{ml}$ of volumetric flask. Add $1 \mathrm{ml}$ of $0.1 \mathrm{~N} \mathrm{NaOH}$ keep the volumetric flask in a water bath at $60^{\circ} \mathrm{C}$ for $2 \mathrm{~h}$. After time period cool the contents to ambient temperature. Neutrilized the solution with $1 \mathrm{ml}$ of $0.1 \mathrm{~N} \mathrm{HCl}$ and volume was made up to $10 \mathrm{ml}$ with diluents. After inject the base degradation sample into HPLC, peak area and peak shape were observed fig. 4.

\section{Procedure for tablet}

The average of 10 tablet was determined and grounded in mortar. An accurately weighed amount of powder equivalent to $10 \mathrm{mg}$ of dapagliflozin was taken. It was transferred to $10 \mathrm{ml}$ of volumetric flask. Add $5 \mathrm{ml}$ of diluents and sonicated for $5 \mathrm{~min}$ to ensure complete solubilization of drug. After sonication, volume was made up to the mark with diluent $(1000 \mu \mathrm{g} / \mathrm{ml}$ of dapagliflozin stock solution). Pipette out $5 \mathrm{ml}$ from above solution and dilute up to 10 $\mathrm{ml}$ with diluent ( $500 \mu \mathrm{g} / \mathrm{ml}$ of dapagliflozin). Pipette out $1 \mathrm{ml}$ from the sample solution and add $1 \mathrm{ml}$ of $0.1 \mathrm{~N} \mathrm{NaOH}$ and keep at $60{ }^{\circ} \mathrm{C}$ in water bath for $2 \mathrm{~h}$. After time period cool the contents to ambient temperature. Neutralized the solution with $1 \mathrm{ml}$ of $0.1 \mathrm{~N} \mathrm{HCl}$ and volume was made up to $10 \mathrm{ml}$ with diluent. After inject the base degradation sample into HPLC, peak area and peak shape were observed fig. 5 .

\section{Peroxide degradation \\ Procedure for API}

Transfer $1 \mathrm{ml}$ of standard solution to $10 \mathrm{ml}$ of volumetric flask. Add $1 \mathrm{ml}$ of $3 \% \mathrm{H}_{2} \mathrm{O}_{2}$, keep the volumetric flask in a water bath at $60{ }^{\circ} \mathrm{C}$ for $2 \mathrm{~h}$. After time period cool the contents to ambient temperature. Dilute the volume with diluent. After inject the peroxide degradation sample into HPLC, peak area and peak shape were observed fig. 6 .

\section{Procedure for tablet}

The average of 10 tablet was determined and grounded in mortar. An accurately weigh the amount of powder equivalent to $10 \mathrm{mg}$ of dapagliflozin was taken. It was transferred to $10 \mathrm{ml}$ of volumetric flask. Add $5 \mathrm{ml}$ of diluents and sonicated for $5 \mathrm{~min}$ to ensure complete solubilization of drug. After sonication, volume was made up to the mark with diluent $(1000 \mu \mathrm{g} / \mathrm{ml}$ of dapagliflozin stock solution). Pipette out $5 \mathrm{ml}$ from above solution and dilute up to 10 $\mathrm{ml}$ with diluent ( $500 \mu \mathrm{g} / \mathrm{ml}$ of dapagliflozin). Pipette out $1 \mathrm{ml}$ from the sample solution and add $1 \mathrm{ml}$ of $3 \% \mathrm{H}_{2} \mathrm{O}_{2}$, keep the volumetric flask in water bath at $60{ }^{\circ} \mathrm{C}$ for $2 \mathrm{~h}$. After time period cool the contents to ambient temperature. Dilute the volume with diluent. After inject the peroxide degradation sample into HPLC, peak area and peak shape were observed fig. 7.

\section{Thermal degradation}

\section{Procedure for API}

Transfer $1 \mathrm{ml}$ of standard solution to $10 \mathrm{ml}$ of volumetric flask. Keep the volumetric flask in water bath at $60{ }^{\circ} \mathrm{C}$ for $2 \mathrm{~h}$. After time period cool the contents to ambient temperature. Make up the volume with diluent. After injecting the thermal degradation sample into HPLC, peak area and peak shape were observed fig. 8 .

\section{Procedure for tablet}

The average of 10 tablet was determined and grounded in mortar. An accurately weigh the amount of powder equivalent to $10 \mathrm{mg}$ of dapagliflozin was taken. It was transferred to $10 \mathrm{ml}$ of volumetric flask. Add $5 \mathrm{ml}$ of diluents and sonicated for $5 \mathrm{~min}$ to ensure complete solubilization of drug. After sonication, volume was made up to the mark with diluents $(1000 \mu \mathrm{g} / \mathrm{ml}$ of dapagliflozin stock solution). Pipette out $5 \mathrm{ml}$ from above solution and dilute up to 10 $\mathrm{ml}$ with diluent $(500 \mu \mathrm{g} / \mathrm{ml}$ of dapagliflozin). Pipette out $1 \mathrm{ml}$ of the sample solution to $10 \mathrm{ml}$ of volumetric flask. Keep the volumetric flask in water bath at $60{ }^{\circ} \mathrm{C}$ for $2 \mathrm{~h}$. After time period cool the contents to ambient temperature. Make up the volume with diluent. After inject the thermal degradation sample into HPLC, peak area and peak shape were observed fig. 9.

\section{Photolytic degradation \\ Procedure for API}

Transfer $1 \mathrm{ml}$ of standard solution to $10 \mathrm{ml}$ of volumetric flask. It was exposed to direct sunlight for $1 \mathrm{~h}$, make up the volume with diluent. After inject the photolytic degradation sample into HPLC, peak area and peak shape was observed fig. 10.

\section{Procedure for tablet}

The average of 10 tablet was determined and grounded in mortar. An accurately weigh the amount of powder equivalent to $10 \mathrm{mg}$ of dapagliflozin was taken. It was transferred to $10 \mathrm{ml}$ of volumetric flask. Add $5 \mathrm{ml}$ of diluents and sonicated for $5 \mathrm{~min}$ to ensure complete solubilization of drug. After sonication, volume was made up to the mark with diluents $(1000 \mu \mathrm{g} / \mathrm{ml}$ of dapagliflozin stock solution). Pipette out $5 \mathrm{ml}$ from above solution and dilute up to 10 $\mathrm{ml}$ with diluents $(500 \mu \mathrm{g} / \mathrm{ml}$ of dapagliflozin). Pipette out $1 \mathrm{ml}$ of the sample solution to $10 \mathrm{ml}$ of volumetric flask. It was exposed to direct sunlight for $1 \mathrm{~h}$, make up the volume with diluent. After inject the photolytic degradation sample into HPLC, peak area and peak shape were observed fig. 11.

\section{Method validation}

System suitability was carried out by injecting standard solutions of API and tablet 5 times into the chromatographic system. The system 
suitability parameters were then evaluated for tailing factor, retention time and theoretical plates of standard chromatograms.

\section{Accuracy}

The accuracy of the test method was demonstrated by \% recovery across its range by making three different concentrations at $50 \%$, $100 \%$ and $150 \%$ level using standard addition method.

\section{Intraday precision}

Intraday precision was performed by injecting standard preparations three times on the day by maintaining the optimized chromatographic conditions and calculate \% relative standard deviation of retention time and peak areas for dapagliflozin.

\section{Inter-day precision}

Inter-day precision was performed by injecting standard preparations three times into chromatographic system on 2 different days by maintaining the optimized chromatographic conditions and calculate \% relative standard deviation of retention time and peak areas for dapagliflozin.

\section{Repeatability}

Method precision of experiment was performed by preparing the standard solutions of Dapagliflozin $(500 \mu \mathrm{g} / \mathrm{ml})$ for six times and analysed as per proposed method and \% RSD was calculated.

\section{Linearity}

Transfer an accurately weighed quantity about $100 \mathrm{mg}$ of dapagliflozin in $100 \mathrm{ml}$ volumetric flask, dissolve and dilute the volume with diluents. Prepare different linearity concentration solutions in the range of $250-750 \mu \mathrm{g} / \mathrm{ml}$.

\section{Robustness}

The robustness was studied by analyzing the sample of dapagliflozin by deliberate variation in method parameters. The change in response of dapagliflozin was noted. Robustness of the method was studied by changing flow rate $\pm 0.2 \mathrm{ml}$, mobile phase composition and column temperature. The change in the response of dapagliflozin was noted and compared with the original one.

\section{Limit of detection and limit of quantification}

LOD and LOQ were determined by using the formula based on the standard deviation of the response and the slope. LOD and LOQ were calculated by using equations:

$\mathrm{LOD}=3.3 \sigma / \mathrm{S}$

$\mathrm{LOQ}=10 \sigma / \mathrm{S}$

Where, $\sigma=$ Standard deviation of response

\section{$\mathrm{S}=$ Slope of calibration curve}

\section{RESULTS AND DISCUSSION}

The detection wavelength was carried out in the UV range of 222 $\mathrm{nm}$. Chromatographic separation was carried out using mobile phase composed 1 molar dipotassium hydrogen phosphate and acetonitrile $(60: 40 \% \mathrm{v} / \mathrm{v})$ and $\mathrm{pH}$ was adjusted to 6.5 with orthophophoric acid on agilent C18 $(4.6 \mathrm{~mm} 150,5 \mu \mathrm{m})$ at a flow rate of $1 \mathrm{ml} / \mathrm{min}$ using PDA detector.

\section{(1) Acid degradation for API and tablet}

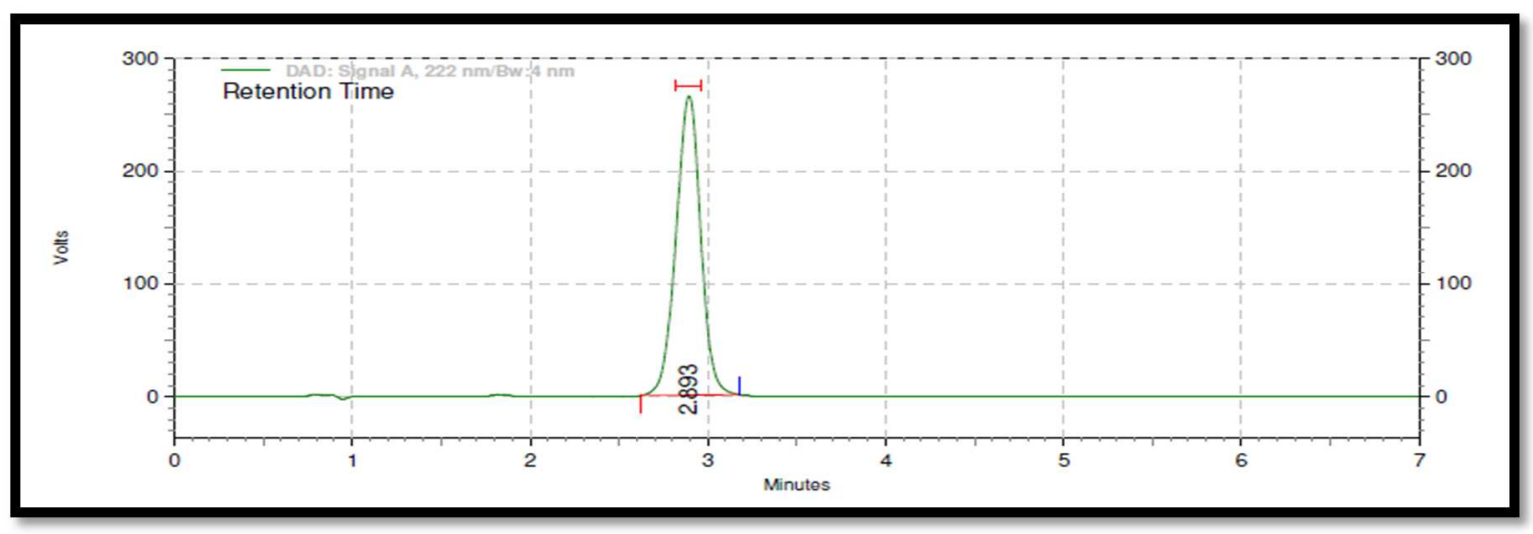

Fig. 2: Acid degradation for dapagliflozin in API

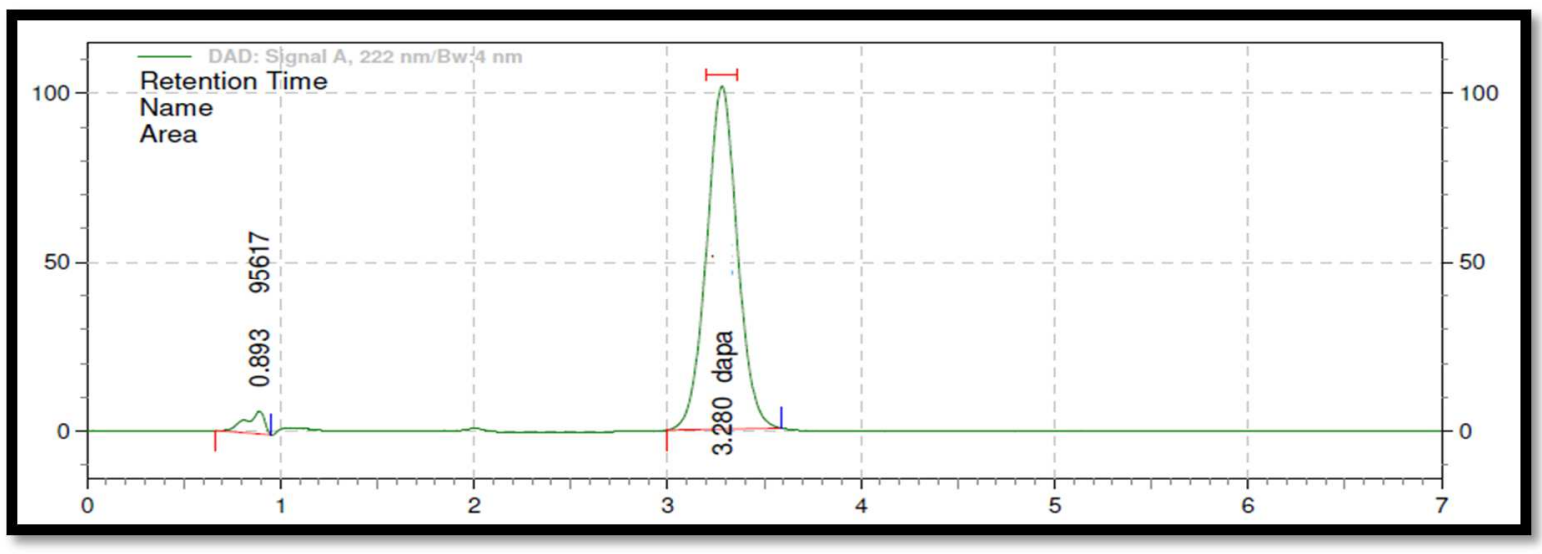

Fig. 3: Acid degradation for dapagliflozin in tablet 
(2) Base degradation for API and tablet

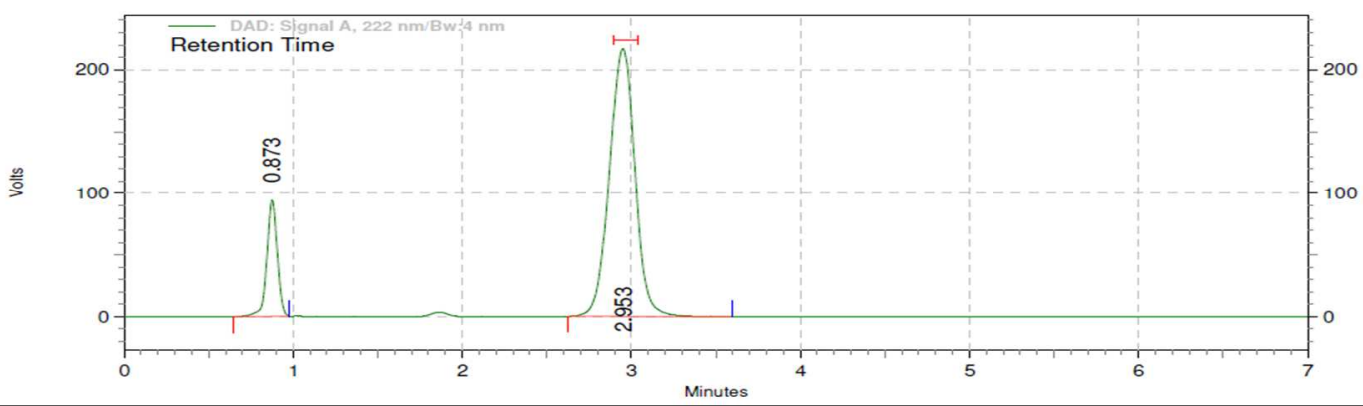

Fig. 4: Base degradation for dapagliflozin in API

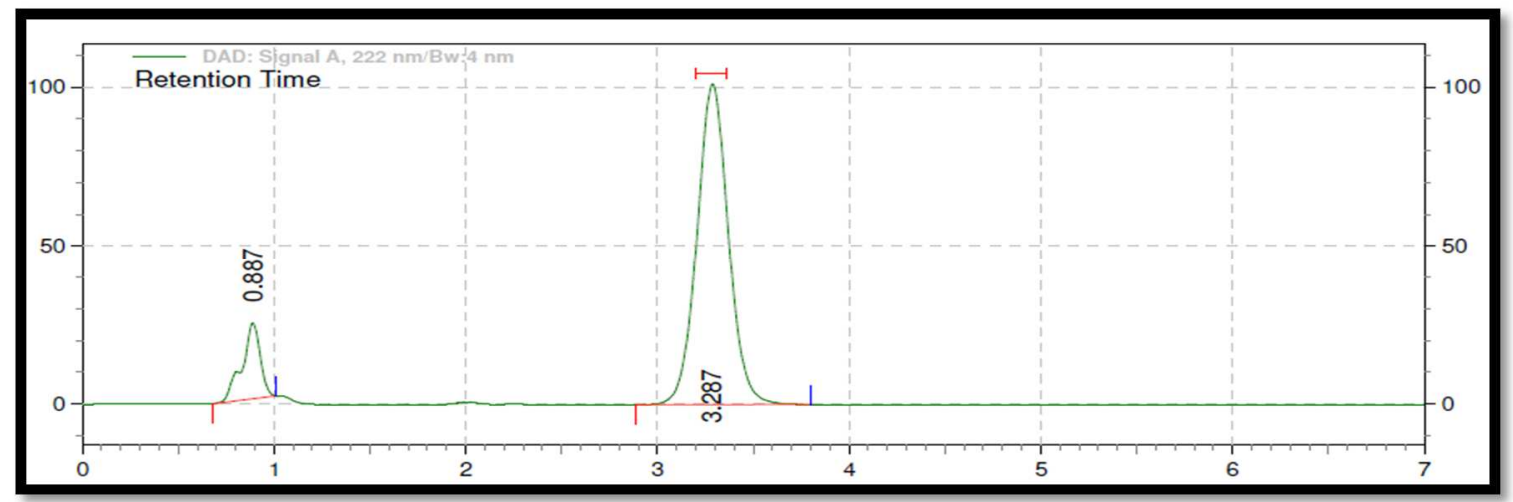

Fig. 5: Base degradation for dapagliflozin tablet

(3) Peroxide degradation

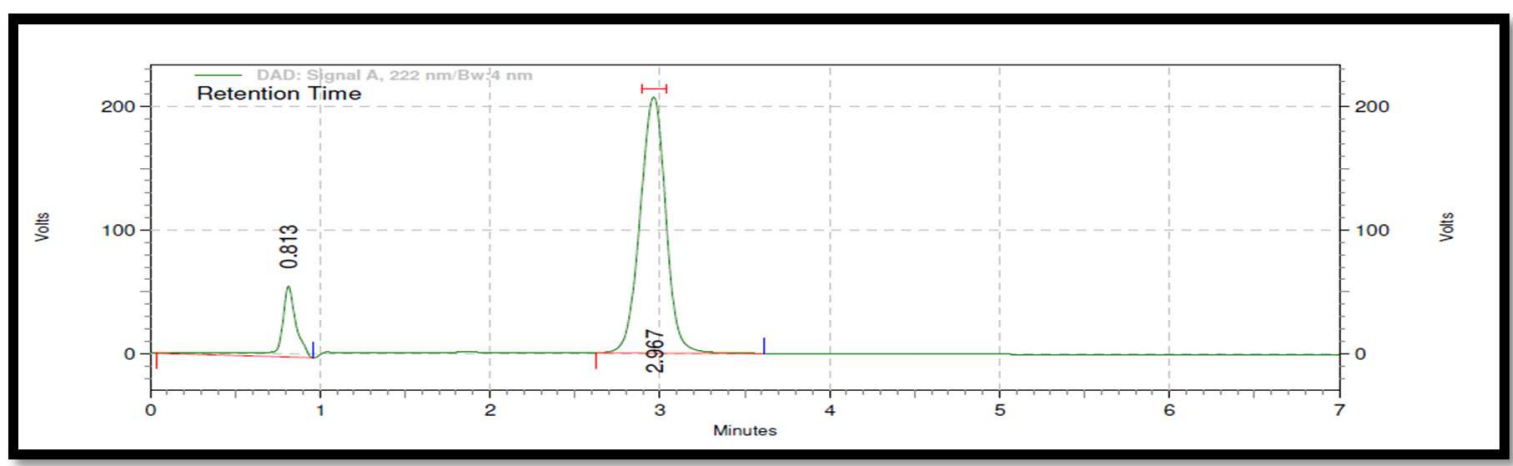

Fig. 6: Peroxide degradation for dapagliflozin API

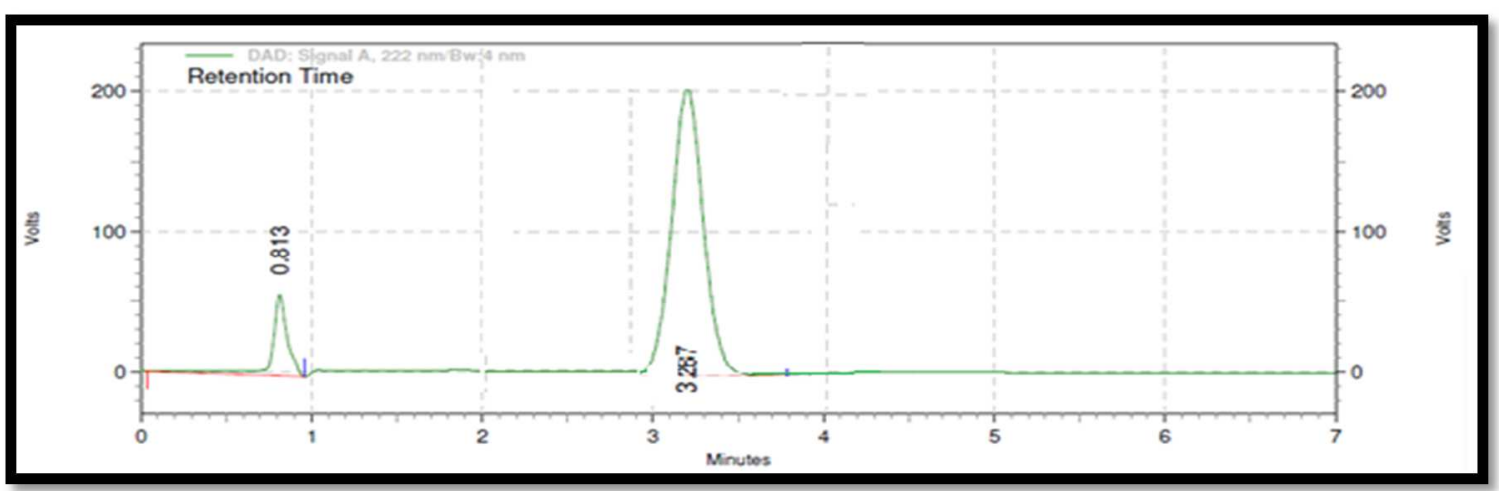

Fig. 7: Peroxide degradation for dapagliflozin tablet 
(4) Thermal degradation

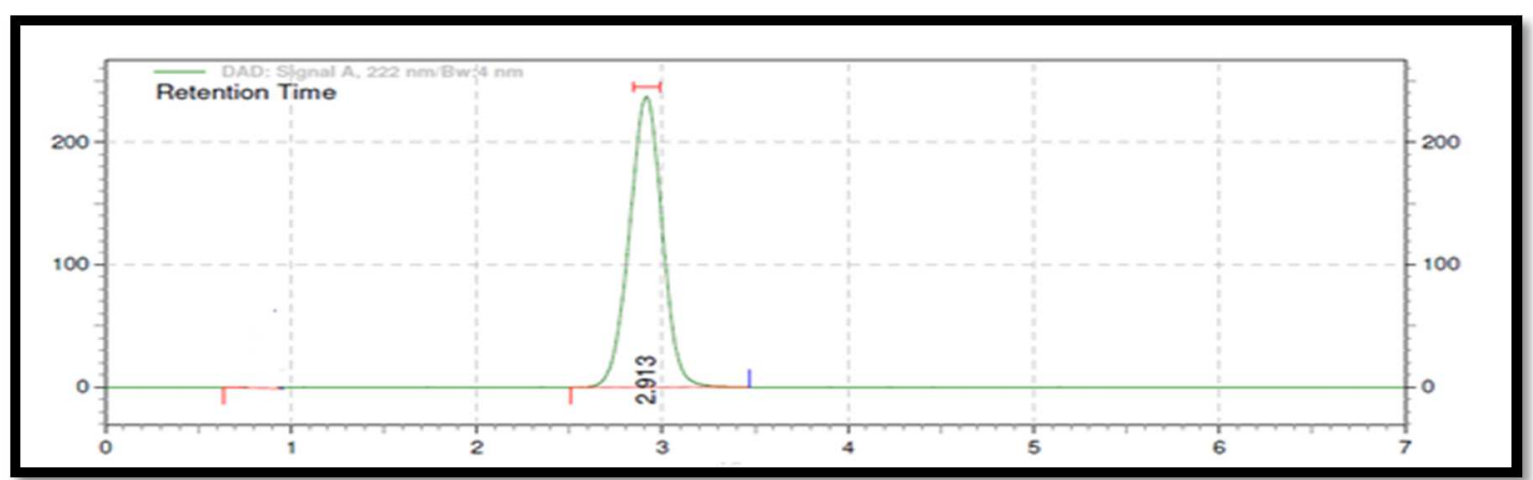

Fig. 8: Thermal degradation for dapagliflozin API

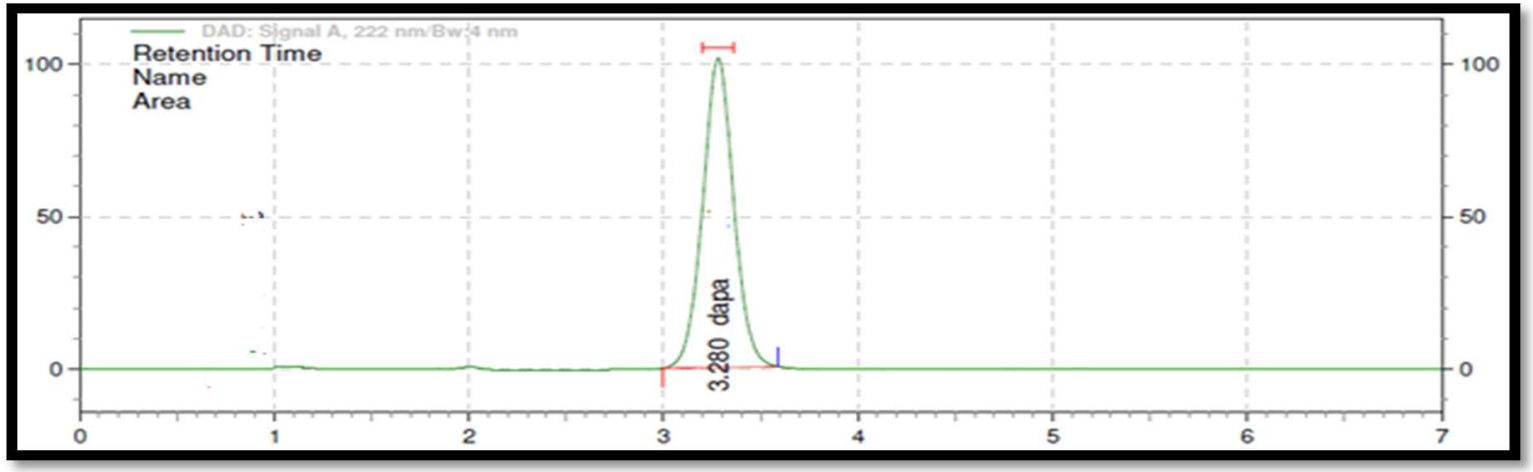

Fig. 9: Thermal degradation for dapagliflozin tablet

(5) Photolytic degradation

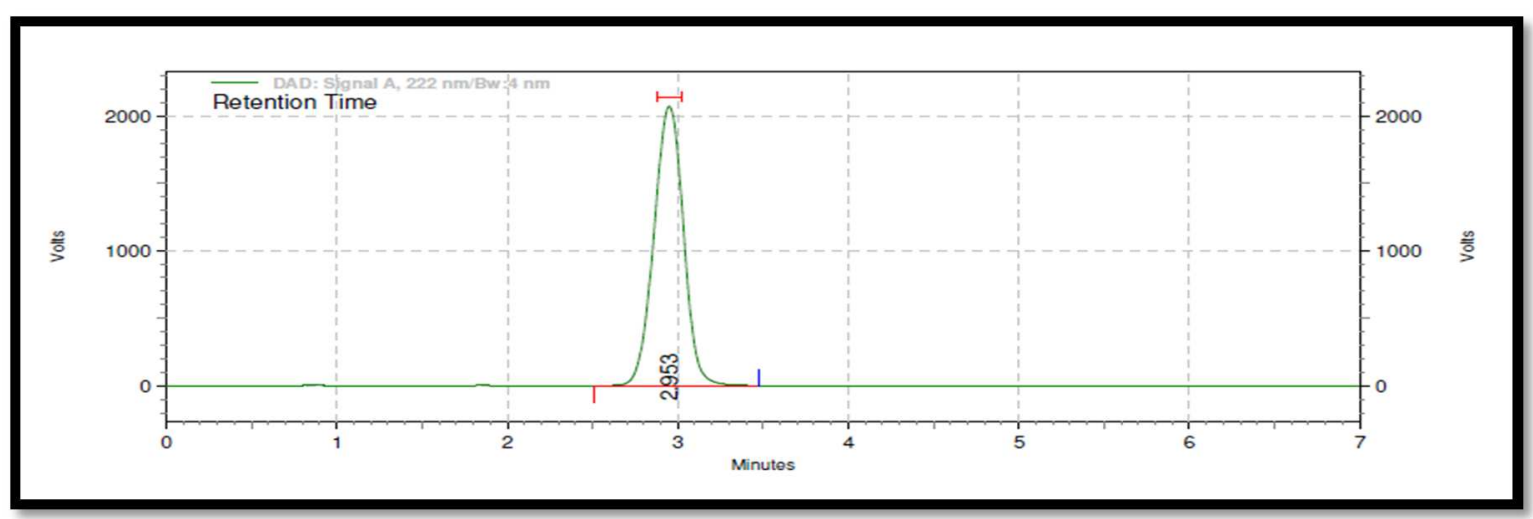

Fig. 10: Photolytic degradation for dapagliflozin API

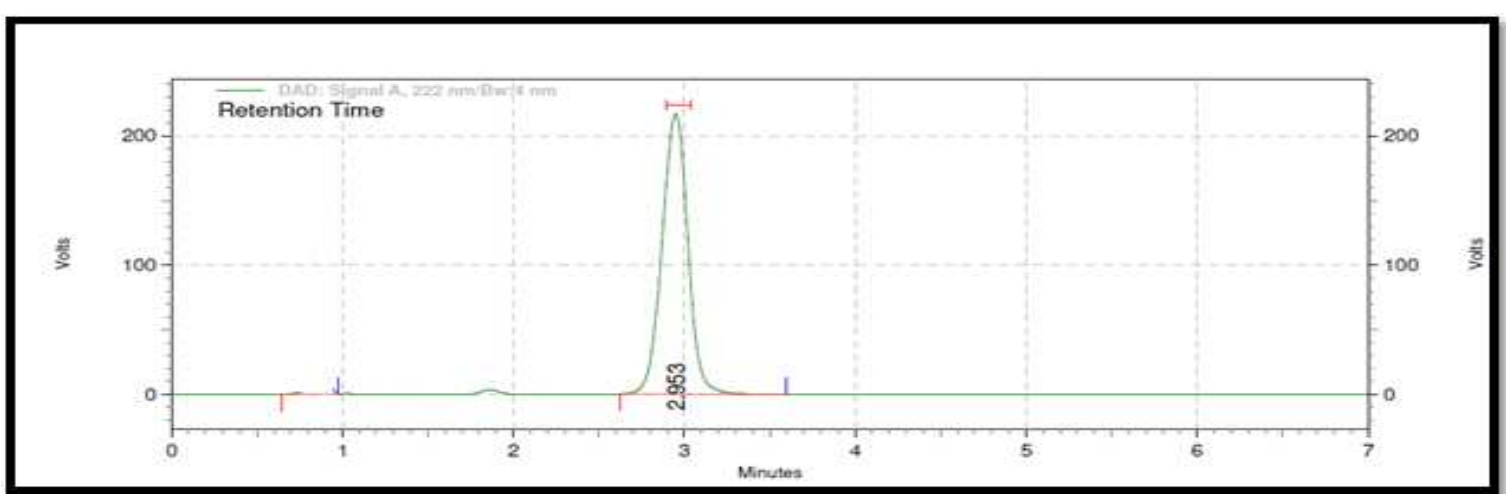

Fig. 11: Photolytic degradation for dapagliflozin 
Tablet 1: Degradation summary for API

\begin{tabular}{|c|c|c|c|}
\hline Type & Solution & Area & \%Degradation \\
\hline As such & Dapagliflozin & 52331398 & - \\
\hline Acid & & & \\
\hline $\begin{array}{l}0.1 \mathrm{~N}^{*} \mathrm{HCL}^{*} \text { at } 60^{\circ} \mathrm{C} \text { for } 2 \mathrm{~h} \text { in water bath } \\
\text { Base }\end{array}$ & Dapagliflozin & 3270712 & $6.25 \%$ \\
\hline $\begin{array}{l}0.1 \mathrm{~N} \mathrm{NaOH}^{*} \text { at } 60^{\circ} \mathrm{C} \text { for } 2 \mathrm{~h} \text { in water bath } \\
\text { Peroxide }\end{array}$ & Dapagliflozin & 27787835 & $5.31 \%$ \\
\hline $\begin{array}{l}3 \% \mathrm{H}_{2} \mathrm{O}_{2}{ }^{*} \text { at Room Temperature for } 3 \mathrm{~h} \\
\text { Thermal }\end{array}$ & Dapagliflozin & 5059869 & $9.66 \%$ \\
\hline $\begin{array}{l}\text { At } 60^{\circ} \mathrm{C} \text { for } 3 \mathrm{~h} \\
\text { Photolytic }\end{array}$ & Dapagliflozin & 6116184 & $11.68 \%$ \\
\hline in sun light for $1 \mathrm{~h}$ & Dapagliflozin & 7849709 & $9.23 \%$ \\
\hline
\end{tabular}

$\mathrm{N}^{*}$-normal, $\mathrm{HCl}^{*}$-hydrochloric acid, $\mathrm{NaOH}^{*}$-sodium hydroxide, $\mathrm{H}_{2} \mathrm{O}_{2}$-hydrogen hydroxide

Table 2: Degradation summary for tablet

\begin{tabular}{|c|c|c|c|}
\hline Type & Solution & Area & \% Degradation \\
\hline $\begin{array}{l}\text { As such } \\
\text { Acid }\end{array}$ & Dapagliflozin & 18920313 & - \\
\hline $\begin{array}{l}0.1 \mathrm{~N}^{*} \mathrm{HCL}^{*} \text { at } 60{ }^{\circ} \mathrm{C} \text { for } 2 \mathrm{~h} \text { in water bath } \\
\text { Base }\end{array}$ & Dapagliflozin & 1500380 & $7.93 \%$ \\
\hline $\begin{array}{l}0.1 \mathrm{~N}^{*} \mathrm{NaOH}^{*} \text { at } 60^{\circ} \mathrm{C} \text { for } 2 \mathrm{~h} \text { in water bath } \\
\text { Peroxide }\end{array}$ & Dapagliflozin & 1738776 & $9.19 \%$ \\
\hline $\begin{array}{l}3 \% \mathrm{H}_{2} \mathrm{O}_{2}{ }^{*} \text { at Room Temperature for } 3 \mathrm{~h} \\
\text { Thermal }\end{array}$ & Dapagliflozin & 1920411 & $10.15 \%$ \\
\hline $\begin{array}{l}\text { At } 60^{\circ} \mathrm{C} \text { for } 3 \mathrm{~h} \\
\text { Photolytic }\end{array}$ & Dapagliflozin & 1651743 & $8.73 \%$ \\
\hline in sun light for $1 \mathrm{hr}$ & Dapagliflozin & 2104050 & $11.12 \%$ \\
\hline
\end{tabular}

$\mathrm{N}^{*}$-normal, $\mathrm{HCl}^{*}$-hydrochloric acid, $\mathrm{NaOH}^{*}$-sodium hydroxide, $\mathrm{H}_{2} \mathrm{O}_{2}$-hydrogen hydroxide

\section{Validation data}

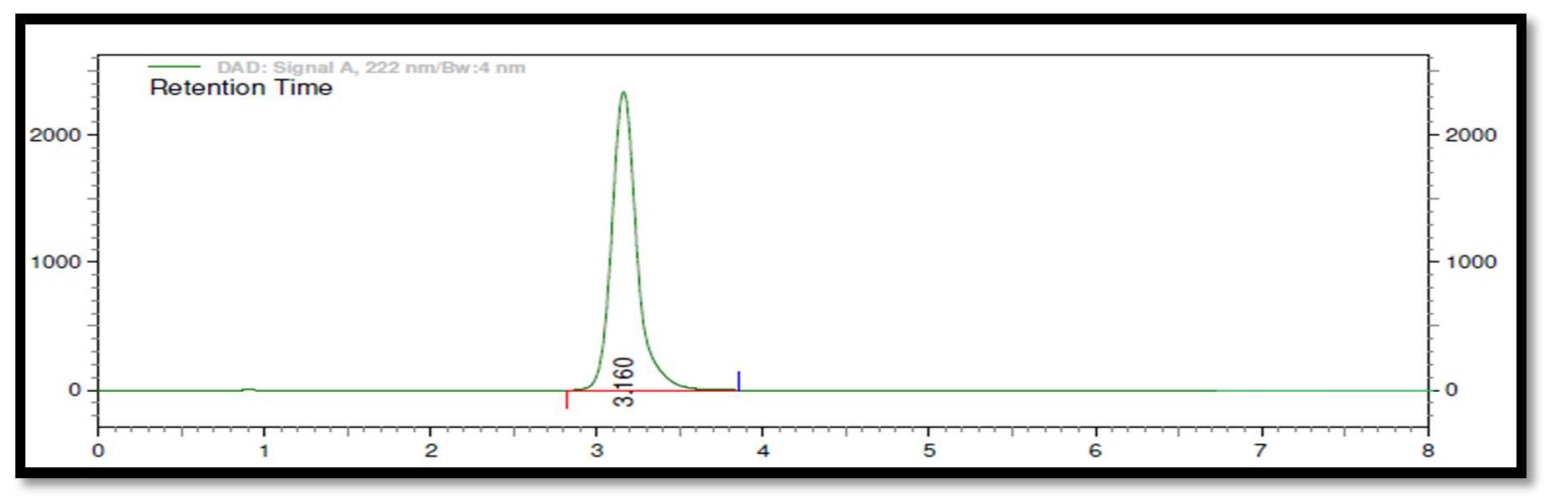

Fig. 12: Chromatogram of API

Table 3: System suitability results (API)

\begin{tabular}{lll}
\hline S. No. & System suitability parameter & Results \\
\hline 1 & Tailing & 1.28 \\
2 & Retention Time & $3.160 \mathrm{~min}$ \\
3 & Plate count & 2350 \\
4 & Area & 5165316 \\
5 & Correlation coefficient & 0.99 \\
6 & LOD $^{*}$ & $5.14 \mu \mathrm{g} / \mathrm{ml}$ \\
7 & LOQ $^{*}$ & $15.6 \mu \mathrm{g} / \mathrm{ml}$ \\
\hline
\end{tabular}

LOD*-Limit of detection, LOQ*-Limit of quantification

Table 4: System suitability results (tablet)

\begin{tabular}{lll}
\hline S. No. & System suitability parameters & Results \\
\hline 1 & Tailing & 1.20 \\
2 & Retention time & 3.067 \\
3 & Plate count & 2030 \\
4 & Area & 18920313 \\
\hline
\end{tabular}




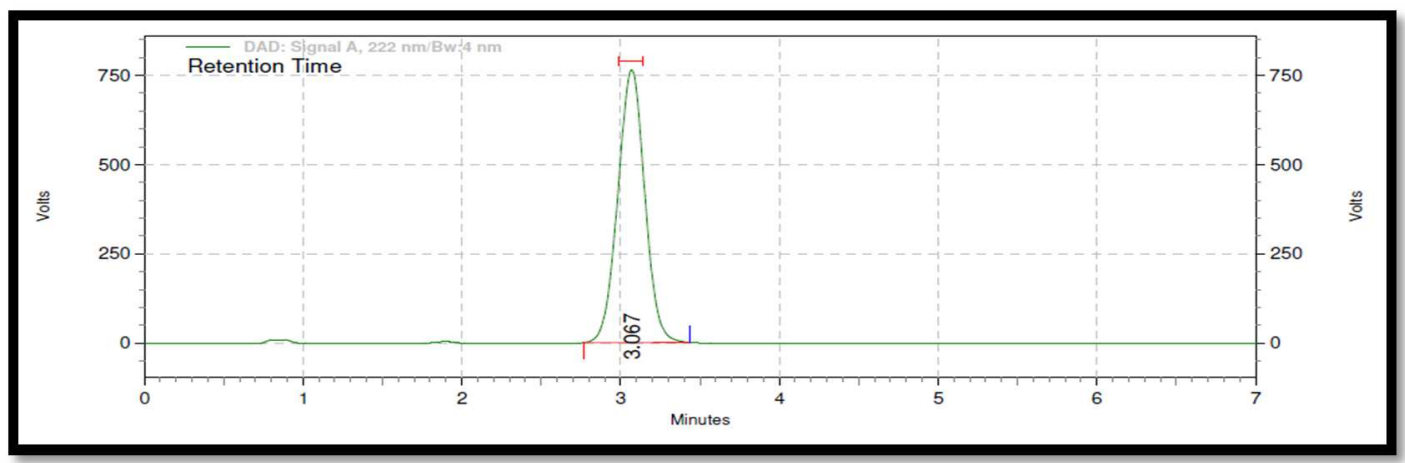

Fig. 13: Chromatogram of tablet

Table 5: System suitability data

\begin{tabular}{|c|c|c|c|}
\hline \multirow[t]{2}{*}{ Parameters } & \multicolumn{2}{|l|}{ Observation } & \multirow[t]{2}{*}{ Specification } \\
\hline & API & Tablet & \\
\hline$\%$ RSD of Area & 0.26 & 0.411 & RSD $<2 \%$ \\
\hline Resolution(Rs) & 0.00 & 0.00 & Rs $>2$ \\
\hline Tailing Factor(T) & $1.28 \pm 0.04$ & $1.02 \pm 0.09$ & $\mathrm{~T} \leq 2$ \\
\hline Theoritical plates(N) & $2350 \pm 185.02$ & $2115.4 \pm 200.36$ & $\geq 2000$ \\
\hline
\end{tabular}

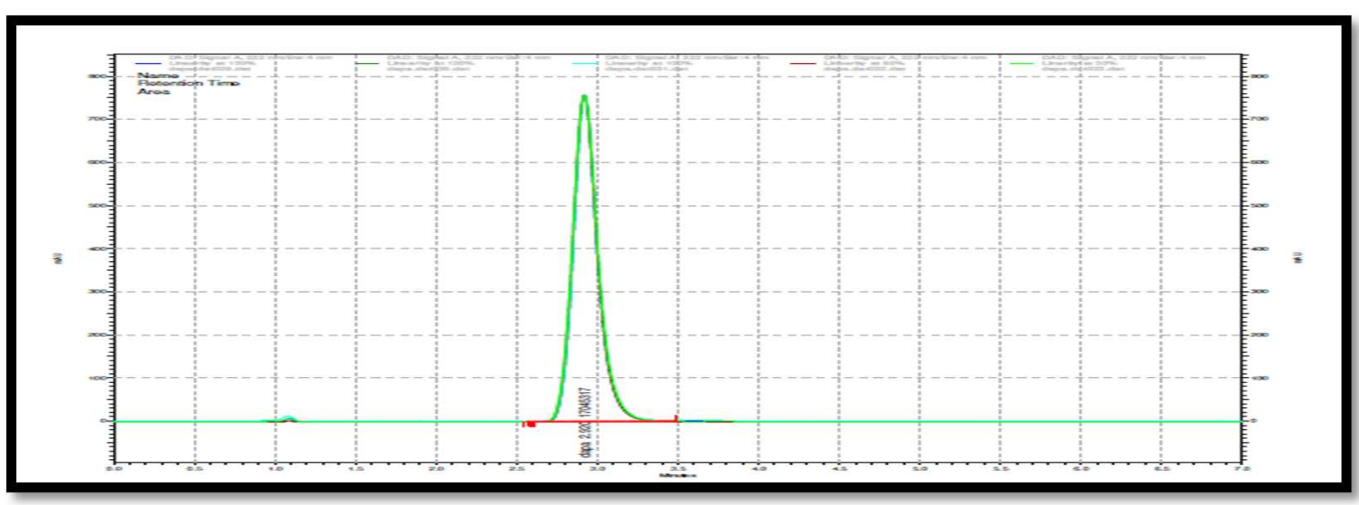

Fig. 14: Overlay spectra of dapagliflozin

Table 6: Linearity data for dapagliflozin

\begin{tabular}{lll}
\hline Conc $^{*}$ & Peak area \pm SD $^{*}(\mathbf{n}=\mathbf{5})$ & \%RSD $^{*}$ \\
\hline 250 & $5274844.2 \pm 11182.6$ & 0.21 \\
400 & $8958845.32 \pm 10236.58$ & 0.12 \\
500 & $11198557.8 \pm 30236.23$ & 0.27 \\
600 & $13438268.54 \pm 50923.2$ & 0.38 \\
750 & $16797835.69 \pm 99983.5$ & 0.59 \\
\hline
\end{tabular}

Number of experiment (n)-5, Conc*-concentration, SD*-standard deviation, \%RSD*-relative standard deviation

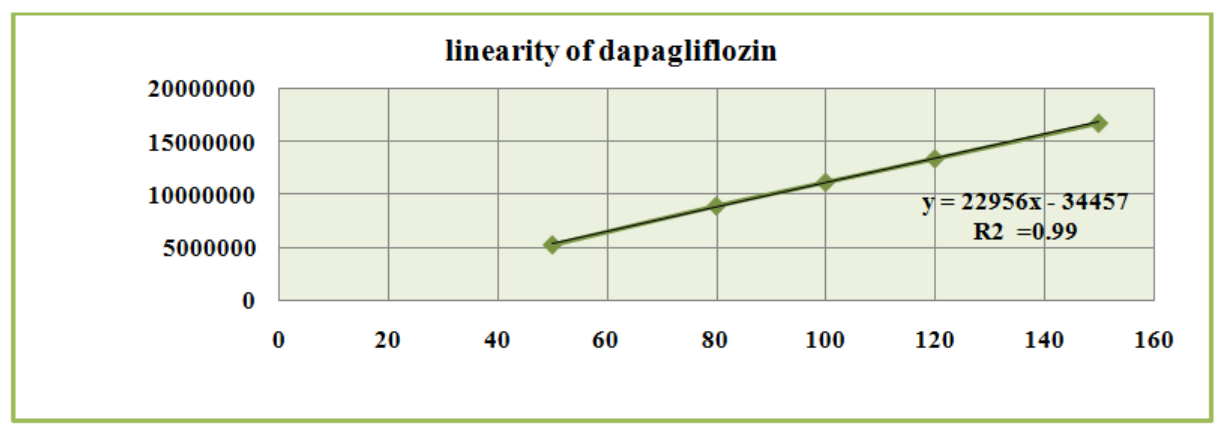

Fig. 15: Calibration plot of dapagliflozin 
Table 7: Accuracy for API and tablet

\begin{tabular}{llll}
\hline Sample & Level (\%) & Amount recovered $(\boldsymbol{\mu g} / \mathbf{m l})$ & Mean \% recovery \pm SD \\
\hline & 50 & $402.96 \pm 0.507$ & $99.72 \pm 0.12$ \\
Dapagliflozin API & 100 & $503.28 \pm 0.55$ & $99.65 \pm 0.109$ \\
& 150 & $601.12 \pm 0.24$ & $99.19 \pm 0.03$ \\
& 50 & $398.65 \pm 0.55$ & $98.67 \pm 0.13$ \\
Dapagliflozin tablet & 100 & $501.98 \pm 0.871$ & $99.40 \pm 0.17$ \\
& 150 & $605.89 \pm 0.98$ & $99.98 \pm 0.16$ \\
\hline
\end{tabular}

Number of experiment $(\mathrm{n})=3, \mathrm{SD}^{*}$-standard deviation, precision study results

Table 8: Intraday precision

\begin{tabular}{lll}
\hline Conc $^{*}(\mu \mathrm{g} / \mathbf{m l})$ & Area \pm SD* & \\
\hline 400 & $11304882.67 \pm 45662.51$ & 0.40 \\
500 & $11205269 \pm 27555.81$ & 0.26 \\
600 & $11368903.33 \pm 23214.27$ & 0.204 \\
\hline
\end{tabular}

Conc*-concentration, Number of experiment (n)-3, SD*-standard deviation, RSD*-relative standard deviation

Table 9: Interday precision

\begin{tabular}{lll}
\hline Conc $^{*}(\mu \mathrm{g} / \mathrm{ml})$ & Area \pm SD & \\
\hline 400 & $11386283 \pm 25806.57$ & \% RSD $^{*}$ \\
500 & $11174585.67 \pm 46710.12$ & 0.23 \\
600 & $11192177 \pm 38642.96$ & 0.42 \\
\hline
\end{tabular}

Conc*-concentration, Number of experiment (n)-3, SD*-standard deviation, RSD*-relative standard deviation

Table 10: Repeatability data

\begin{tabular}{ll}
\hline S. No. & Dapagliflozin $(\mathbf{5 0 0} \boldsymbol{\mu g} / \mathbf{m l})$ \\
\hline 1 & 11448945 \\
2 & 11367925 \\
3 & 11382354 \\
4 & 11283925 \\
5 & 11356486 \\
6 & 11345685 \\
Mean & 11364220 \\
SD $^{*}$ & 11596.78 \\
\% RSD & 0.102 \\
\hline
\end{tabular}

Number of experiment (n)-6, SD*-standard deviation, RSD*-relative standard deviation

Table 11: Robustness study

\begin{tabular}{|c|c|c|c|c|c|c|}
\hline \multirow[t]{2}{*}{ Conc $^{*}(500 \mu \mathrm{g} / \mathrm{ml})$} & \multicolumn{2}{|l|}{ Flow rate } & \multicolumn{2}{|c|}{ Temperature $\left({ }^{\circ} \mathrm{C}\right)$} & \multicolumn{2}{|c|}{ Mobile Phase } \\
\hline & $0.8 \mathrm{ml}$ & $1.2 \mathrm{ml}$ & $25^{\circ}$ & $35^{\circ}$ & $+5 \mathrm{ml}$ & $-5 \mathrm{ml}$ \\
\hline Avg. area & 66176464 & 5234741 & 1456537.3 & 1856685 & 18478292.3 & 43198353 \\
\hline $\mathrm{SD}^{*}$ & 78967.96 & 5998.1 & 12044.42 & 102585 & 132229.6 & 20341.1 \\
\hline \% RSD* & 0.11 & 0.11 & 0.83 & 0.55 & 0.83 & 0.12 \\
\hline
\end{tabular}

Conc ${ }^{*}$-concentration, Number of experiment (n)-3, SD*-standard deviation, RSD*-relative standard deviation

Table 12: LOD and LOQ

\begin{tabular}{ll}
\hline Parameter & Dapagliflozin \\
\hline $\operatorname{LOD}^{*}(\mu \mathrm{g} / \mathrm{ml})$ & 5.14 \\
$\operatorname{LOQ}^{*}(\mu \mathrm{g} / \mathrm{ml})$ & 15.6 \\
\hline
\end{tabular}

LOD*-limit of detection, $\mathrm{LOQ}^{*}$-limit of quantification

\section{DISCUSSION}

A new stability indicating RP-HPLC method has been developed for estimation of Dapagliflozin in API and Tablet dosage form was rapid, accurate, precise, specific, sensitive and robust.
From the above study, we can conclude that the dapagliflozin was subjected to acid, alkali hydrolysis, and oxidation, thermal and photolytic degradation. The degradation studies indicate that dapagliflozin is more susceptible to thermal degradation and Forxiga is more susceptible to photolytic degradation. 
From the peak purity study, it was confirmed that the peak of degradation product and excipient was not interfering with the peak of the drug. Hence this method was used for the analysis of Dapagliflozin in API and tablet dosage form in quality control department for routine analysis.

Linearity of the developed method follows beer's law and was near to 0.99 . It found to be linear in the range $250-750 \mu \mathrm{g} / \mathrm{ml}$. \% RSD was found to be less than 2 for precision. The method is robust since by deliberate variation in method, \% RSD was found to be less than 2 . So the is found to be robust.

\% Recoveries was found to be $99.65 \%$. Hence this method can be used for analysis of dapagliflozinin API and Tablet dosage form in quality control department for routine analysis.

\section{CONCLUSION}

In the present study, we have developed a new, rapid RP-HPLC method and validated for different parameters (system suitability, linearity, accuracy, precision, LOD, LOQ robustness). By studying all these we have concluded that the method was linear, accurate, precise, robust and rapid for determination of dapagliflozin in API and Pharmaceutical dosage form. Hence the method was successfully applied for the estimation of dapagliflozin in API and Pharmaceutical dosage form

\section{ACKNOWLEDGEMENT}

The authors are thankful to advanced analytical research and training institute for providing all the facilities to complete research work.

\section{CONFLICT OF INTERESTS}

Declare none

\section{REFERENCES}

1. Drug Profile; 2016. http://www.drugbank.ca/drugs/DB06292. [Last accessed on 10 Mar 2017].

2. Obermeier M, Yao M, Khanna A, Koplowitz B, Zhu M, Li W, et al. In vitro characterization and pharmacokinetics of dapagliflozin (BMS-512148), a potent sodium-glucose cotransporter type II inhibitor, in animals and humans. Drug Metab Dispos 2010;38:405-14.
3. Sanagapati Manasa, Dhanlakshmi K, G Nagarjuna, B Kavitha. Method development and validation of dapagliflozin API by UV spectroscopy. Int J Pharm Sci Res 2014;27:270-7.

4. KP Chitra, Eswaraiah MC, Rao Basoveswara MV. Unique UV spectrophotometric method for the reckoning of dapagliflozin in bulk and pharmaceutical dosage form. J Chem Pharm Res 2015;7:45-5.

5. Jani Br, Shah KV, Kapupara PP. Development and validation of UV spectroscopic method for simultaneous estimation of dapagliflozin and metformin hydrochloride in the synthetic mixture. Int J Res Dev Pharm Life Sci 2015;4:1569-7.

6. Jani BR, Shah KV, Kapupara PP. Development and validation of UV spectroscopic first derivative method for simultaneous estimation of dapagliflozin and metformin hydrochloride in the synthetic mixture. J Bioequv 2015;1:1-8.

7. Sanagapati Manasa, Dhanlakshmi K, G Nagarjunareddy, Sreenivasa S. Development and validation of a RP-HPLC method for the estimation of dapagliflozin in API. Int J Pharm Sci Res 2014:5394-3.

8. Yunoos Mohammad, DS Gowri. A validated stability indicating HPLC method for simultaneous determination of metformin hydrochloride and dapagliflozin in bulk drug and tablet dosage form. A J Pharm Clin Res 2015;8:320-6.

9. Sanagapati Manasa, Dhanlakshmi K, G Nagarjunareddy. Method development and validation of dapagliflozin in API by RP-HPLC and UV spectroscopy. Int J Pharm Sci Drug Res 2014;6:250-2.

10. Sanagapati Manasa, Dhanlakshmi K, G Nagarjunareddy, S Sreenivasa. Development and validation of stability indicating RP-HPLC method for determination of dapagliflozin. J Adv Pharm Edu Res 2014;4:350-3.

11. Aubry Af, Gu H, Magnier R, Morgan L, Xu X, Tirmenstein M, et al. Validated LC-MS/MS methods for the determination of dapagliflozin a sodium glucose co-transporter 2 inhibitors in normal and ZDF rat plasma. Bioanalysis 2010;2:1.

\section{How to cite this article}

- $\quad$ Mitali V Verma, Chirag J Patel, MM Patel. Development and stability indicating HPLC method for dapagliflozin in api and pharmaceutical dosage form. Int J Appl Pharm 2017;9(5):33-41. 